\title{
Silage quality, Performance Characteristics and Blood Parameters of West African Dwarf (WAD) Goats Fed Vetiver Grass (Chrysopogon zizanioides L. Roberty) Ensiled With Cassava Peels
}

* Falola, O. O., Adedeji., O. Y., Saka, A. A, Adegbite, O.O. and Adisa, A. F. Federal College of Animal Health and Production Technology, Ibadan, Oyo State, Nigeria * Correspondence author: oyenikeolubunmi@yahoo.com

\begin{abstract}
Four week old vetiver grass (Chrysopogon zizanioides L. Roberty) (VG) was harvested and ensiled with cassava peels (CPL) at different ratios viz: (A) 80VG:20\%CPL, (B) 70VG:30\%CPL, (C) 60VG:40CPL, (D) 50VG:50CPL, (E) 100VG:0CPL. The various mixtures of $V G$ and $C P L$ were ensiled for 42 days after which the silage characteristics were determined. The silage from the different mixing ratios of $V G$ and $C P L$ were fed for 105 days. Silages with cassava peels had acceptable colour of olive green, pleasant alcoholic odour, and $\mathrm{pH}$ range of 4.23-4.50. While 100\%VG ensiled without CPL had undesirable characteristics such as pungent odour, brownish colour, mouldy growth and $p H$ of 5.5.Treatments E (100\% VG:0\%CPL)was unfit for feeding due to its undesirable characteristics, therefore sixteen West African Dwarf (WAD) goats were randomly allotted to four dietary treatments in a completely randomised design. Weight gain, feed intake, digestibility and some blood parameters were determined. The feed intake (341.14 $358.21 \mathrm{~g} / \mathrm{DM})$ was not significant among the treatments while the weight gain (23.93 $26.93 \mathrm{~g} / \mathrm{d})$ and dry matter digestibility (63.91 - 66.81\%) were significant across the treatments. Packed cell volume $(31.0-33.0 \%)$, heamoglobin $(10.3-12.7)$, total protein $(8.40-9.04 \mathrm{~g} / \mathrm{dl})$ and blood urea $(12.08-12.32 \mathrm{mg} / \mathrm{dl})$ was significantly different among the treatments. It was concluded that feed intake, digestibility and body weight gain increased as level of cassava peels increased in the silage.
\end{abstract}

Keywords: Vetiver grass, Cassava peels, silage properties, intake and digestibility

Introduction

Forages, crop residues and by-products are usually consumed fresh by domestic animals. However, it is possible to conserve them for use during future periods of feed shortage. Conservation can be achieved by sun drying (hay) and by fermentation (silage). Hay making is difficult in the tropical region because at the time when the forage is of acceptable quality for conservation (early in the wet season), the weather is likely to be too unreliable for sun drying and artificial drying is expensive also facilities are not widely available (Mannetje, 1999). Fermentation by silage making can be done using fresh or preferably wilted materials. Ensiling is the preservation of forage, crop residues and by-products based on lactic acid fermentation under anaerobic condition. The lactic acid bacteria ferment the plant sugars (water soluble carbohydrates) in the crop to lactic acid (Mannatje, 1999). Ensiling is done to preserve forage resources for the dry season in the tropics in order to ensure a continuous regular feed for livestock to sustain growth, for fattening or milk production.

Vetiver grass is a perennial grass of tropical origin, it is commonly cultivated for the scented oil that can be distilled from its roots (NRC, 1993). Vetiver grass plays an 
important role in erosion and sediment control, as well as being tolerant to extreme soil conditions (Troug and Baker, 1998). The use of Vetiver as a dual purpose forage by small holder farmers in the rain-fed upland areas of the Philippines was mentioned by Lapar and Ehui (2003). In addition, Vetiver grass was reported to be edible herbage of high quality for cattle and goats particularly in the growing stage (Liu and Cheng, 2002). Vetiver grass is considered to be a promising feed resource because of its high quality, fast growth rate and easy adaptation to the environment and ability to bear repetitive mowing without occupying farm land. Cassava peels has been regularly used by farmers to feed goats due to its availability all year round. It can serve as a good silage additive to increase the nutritional value, improve fermentation and enhance intake of vetiver grass. The objectives of this study was to determine the silage quality of vetiver grass using cassava peels as additive, dry matter intake, digestibility and some blood metabolites of WAD goats fed Vetiver grass ensiled with cassava peels.

\section{Materials and Methods \\ Experimental site}

The experiment was carried out at the sheep and goat unit of National Center for Genetic Research and Biotechnology (NAGRAB), Moor-Plantation, Ibadan, (Latitude $7^{0} 15^{1}-$ $7^{0} 30^{\prime} \mathrm{N}$ and Longitude $3^{0} 45^{1}-4^{0} \mathrm{E}$ ).

\section{Silage making}

Vetiver grass was harvested at 4-week of regrowth from an existing experimental pasture plot of FCAH and PT, Moor Plantation, Ibadan, Nigeria. (Latitude $7^{0} 15^{1}$ $-7^{0} 30^{1} \mathrm{~N}$ and Longitude $3^{0} 45^{1}-4^{0} \mathrm{E}$ ).

Fresh cassava peels were obtained at a nearby garri processing centre. The harvested grasses were chopped manually to about $3 \mathrm{~cm}$ length for ease of compaction and consolidation of silage. Filling and compaction was done simultaneously to eliminate inherent air. The silage was prepared in $20 \mathrm{~kg}$ polythene bags each. The bags were then sealed and compressed with piles of heavy sand bags and fermentation was done for 42 days. The treatments were as follows: (A) $80 \mathrm{VG}: 20 \% \mathrm{CPL}$, (B) 70VG:30\%CPL, (C) 60VG:40CPL, (D) 50VG:50CPL, (E) 100VG:0CPL. . After 42days, the silages were opened for determination of silage quality. The quality indices of colour, aroma, texture, $\mathrm{pH}$ and temperature were assessed according to Babayemi and Igbekoyi (2008).

Experimental Animal and Management: Sixteen WAD goats of weight ranging between $6-9 \mathrm{~kg}$ were used for this study in a completely randomized design with four goats per treatment. On arrival, animals were given prophylactic treatments consisting of oxytetracycline long acting antibiotic $(1 \mathrm{ml} / 10 \mathrm{~kg}$ body weight of the animal). They were also drenched with albendazole to control endoparasites and treated for mange and other ectoparasites using Ivomec ${ }^{(R)}$. They were later vaccinated against Pestes des petits ruminante (PPR) using a tissue culture Rinderpest Vaccine. The goats were kept in individual pens and were fed $5 \%$ of their body weight with the silage for 105 days. Daily feed offered and refusals were weighed to determine feed intake. Weight gain was determined weekly. At the last seven days of the experiment the goats were transferred to individual metabolic cages for the digestibility studies. About $10 \%$ of total daily faecal outputs collected from each animal were taken to the Laboratory; samples were oven drying at $65^{\circ} \mathrm{C}$ for dry matter determination. At the end of the experiment blood samples were collected through jugular vein into specimen bottles with Ethylene Di-amine Tetra Acetic acid 
(EDTA) for heamatological analysis. Blood samples for serum biochemical analysis were allowed to clot. The packed cell volume (PCV) and haemoglobin $(\mathrm{Hb})$ were determined using micro haematocrit method and cyanmethaemoglobin method as described by Mitruka and Rawnsley (1977). Total protein was determined by using the biurette method as described by Coles (1986). Urea was determined by urease method and creatine by Folinwu filtrate methods as described by Toro and Ackermann (1975).Proximate composition of the silages and faecal output was done according to the methods of AOAC (1990). Fibre fractions were determined as described by van Soest et al.(1991).

Statistical Analysis

The experimental design was completely randomized design (CRD). Data obtained were subjected to analysis of variance (ANOVA) using the procedure of SAS (2002).

\section{Results and Discussion}

Table 1 shows the silage qualities of the vetiver grass ensiled with cassava peels. Differences were not observed in all the parameters measured. All the silages had olive green colour characterised by pleasant alchoholic odour, temperature of $20^{\circ} \mathrm{C}$ and firm in texture. $\mathrm{pH}$ ranged from 4.23-4.50, except for vetiver ensiled without cassava peels which exhibited poor silage quality such as pungent smell, brownish green colour, mouldy growth and $\mathrm{pH}$ of 5.5 . Good silage usually preserves well the original colour of the pasture (Mannatje, 1999). The olive green colour was close to the original colour of the grass, which was an indication of good quality silage that was well preserved (Oduguwa et al., 2001). The $\mathrm{pH}$ value (4.23-4.50) was within the range of (3.50-5.50) classified to be $\mathrm{pH}$ for good silage (Meneses et al., 2007). Generally, pH is one of the quickest and simplest way of evaluating silage quality. Silage that has been properly fermented will have a much lower pH. Kung and Shaver (2002) in their interpretation of silage analysis stated that $\mathrm{pH}$ values for good quality grass and legume silage, in the tropics should range from 4.3 to 4.7. Temperature is another essential factor that affects silage quality and colour, temperature above $30^{\circ} \mathrm{C}$ will result in dark silage due to caramelization of sugars in the forage (McDonald et al., 1995). All the silages with cassava peel were firm in texture which was also an indication of good silage (Kung and Shaver, 2002).

Chemical composition of the silages is presented in Table 2. Crude protein decreased with increasing level of cassava peels. This is due to the lower Crude Protein content of cassava peels compared with Vetiver grass. Increasing proportion of cassava peels reduced the fibre contents of the silage. The crude protein value (8.48$8.97 \%$ ) obtained was higher than the normal range of $(7.7 \%)$ which is the critical value recommended for small ruminants (NRC, 1981) and lower than the minimum protein requirement of $10-12 \%$ recommended by ARC (1985) for ruminants.

Feed intake of the silages by WAD goat is presented in table 3 . Feed intake varied from $(341.14 \mathrm{~g} /$ day $)$ on Silage A (80VG:20\%CPL) to (358.2g/day) on Silage D (50VG:50CPL). Increasing the level of cassava peels in the silage mixture increased the intake which is an indication of the positive effect of cassava peels on intake, The feed intake (g/d) of goats in this experiment were higher than the range reported by Nguyen et al. (2004) when Teen goats were fed with vetiver hay supplemented with some tree foliages Intake was also higher than the values 
Silage quality and performance characteristics and blood parameters goats fed vetiver grass

Table 1: Silage characteristics of Vetiver grass ensiled with cassava peels

\begin{tabular}{llllll}
\hline Parameters & $100 \% \mathrm{VG}: 0 \%$ & $80 \% \mathrm{VG}:$ & $70 \% \mathrm{VG}:$ & $60 \% \mathrm{VG}:$ & $50 \% \mathrm{VG}$ \\
& $\mathrm{CPL}$ & $20 \% \mathrm{CPL}$ & $30 \% \mathrm{CPL}$ & $40 \% \mathrm{CPL}$ & $50 \% \mathrm{CPL}$ \\
\hline Colour & Brownish & $\begin{array}{l}\text { Olive } \\
\text { green }\end{array}$ & $\begin{array}{l}\text { Olive } \\
\text { green }\end{array}$ & $\begin{array}{l}\text { Olive } \\
\text { green }\end{array}$ & $\begin{array}{l}\text { Olive } \\
\text { green }\end{array}$ \\
Odour & Pungent smell & $\begin{array}{l}\text { Pleasant/ } \\
\text { alcoholic }\end{array}$ & $\begin{array}{l}\text { Pleasant/ } \\
\text { alcoholic }\end{array}$ & $\begin{array}{l}\text { Pleasant/ } \\
\text { alcoholic }\end{array}$ & $\begin{array}{l}\text { Pleasant/ } \\
\text { alcoholic }\end{array}$ \\
Texture & Mouldy/slimm & Firm & Firm & Firm & Firm \\
& y & & & & \\
Temperature $\left({ }^{\circ} \mathrm{C}\right)$ & 30.0 & 20.0 & 20.0 & 20.0 & 20.0 \\
$\mathrm{Ph}$ & 5.50 & 4.50 & 4.43 & 4.39 & 4.23 \\
\hline
\end{tabular}

Table 2: Chemical composition (g/100g DM) of Vetiver grass (VG) ensiled with cassava peels

\begin{tabular}{lllllll}
\hline Parameters & $100 \% \mathrm{VG}:$ & $80 \% \mathrm{VG}:$ & $70 \% \mathrm{VG}:$ & $60 \% \mathrm{VG}:$ & $50 \% \mathrm{VG}:$ & $\pm \mathrm{SEM}$ \\
& $0 \% \mathrm{CPL}$ & $20 \% \mathrm{CPL}$ & $30 \% \mathrm{CPL}$ & $40 \% \mathrm{CPL}$ & $50 \% \mathrm{CPL}$ & \\
\hline Crude fibre & 2443 & 24.33 & 23.87 & 22.65 & 22.61 & 3.54 \\
Crude protein & 8.98 & 8.97 & 8.72 & 8.52 & 8.48 & 0.51 \\
Ether extract & 9.23 & 9.32 & 9.37 & 9.42 & 9.39 & 0.23 \\
Ash & 9.69 & 9.73 & 9.77 & 9.82 & 10.05 & 0.32 \\
NDF & 48.87 & 48.68 & 45.73 & 43.75 & 40.81 & 7.89 \\
ADF & 27.87 & 27.69 & 25.75 & 22.75 & 21.45 & 6.24 \\
ADL & 7.81 & 7.69 & 7.52 & 7.34 & 7.24 & 0.45 \\
\hline
\end{tabular}

reported by Fasae et al. (2012), when WAD goats were fed cassava residues. The differences in intake might be attributed to diets constituent and the breed of goat used. Body weight gain was directly proportional to feed intake and digestibility, goats on Silage D having the highest $(26.34 \mathrm{~g} / \mathrm{d})$ while the lowest was observed for goats on Silage A (23.93g/d). Weight gain observed in this study was lower than values reported by Fasae et al. (2012) for goats fed cassava residues. The DM Digestibility ranged from $63.91 \%$ in Silage A to $66.81 \%$ in Silage D. Dry matter digestibility increased with increased inclusion level of cassava peels. The range (63.91-66.79\%) obtained in this study for DM digestibility were lower than $77.68 \%$ and $84.24 \%$ reported by Nguyen et al, (2004) and Aderinola et al. (2008) respectively in goats fed fresh vetiver grass. However there was no significant difference $(\mathrm{P}>0.05)$ observed in the feed conversion ratio among the treatments indicating that the silages were equally utilized by the animals. The range (76.71 $77.81 \%$ ) obtained for Crude protein digestibility in this study were lower than $83.54 \%$ obtained by Aderinola et al. (2008) and higher than the range (62.04 -66.91\%) obtained by Nguyen et al. (2004) when Teen goats was fed with vetiver grass supplemented with tree foliages (Sesbania grandiflora, Leuceana leucocephala and Trichantera gigantea). Apparent nutrient digestibility of WAD goats fed the experimental silages were not significantly $(P>0.05)$ different among the treatments. The variation obtained in the values could be attributed to different breeds of goat used, geographical location and different dietary supplements. Packed cell volume (PCV) $(31-33 \%)$, were significantly 
Table 3: Dry matter intake, live weight gain, nutrient digestibility and blood parameters of WAD goats fed vetiver grass ensiled with cassava peels.

\begin{tabular}{llllll}
\hline Parameters & A & B & C & D & SEM \\
\hline Goat performance & & & & & \\
Feed intake(g/day) & 341.14 & 349.10 & 355.05 & 358.12 & 22.25 \\
Weight gain(g/day) & $23.93^{\mathrm{b}}$ & $24.40^{\mathrm{ab}}$ & $25.01^{\mathrm{a}}$ & $26.34^{\mathrm{a}}$ & 0.90 \\
& & & & & \\
Feed conversion ratio & $14.46^{\mathrm{a}}$ & $14.30^{\mathrm{a}}$ & $14.19^{\mathrm{b}}$ & $13.79^{\mathrm{c}}$ & 2.21 \\
& & & & & \\
Digestibility (\%) & & & & \\
Dry matter & $63.91^{\mathrm{c}}$ & $65.42^{\mathrm{b}}$ & $66.79^{\mathrm{a}}$ & $66.81^{\mathrm{a}}$ & 2.88 \\
Crude protein & $77.81^{\mathrm{a}}$ & $77.68^{\mathrm{a}}$ & $76.71^{\mathrm{b}}$ & $76.98^{\mathrm{a}}$ & 1.10 \\
Crude fiber & $82.97^{\mathrm{a}}$ & $83.33^{\mathrm{a}}$ & $80.42^{\mathrm{b}}$ & $77.23^{\mathrm{a}}$ & 2.91 \\
Ether extract & $76.71^{\mathrm{b}}$ & $77.68^{\mathrm{a}}$ & $77.73^{\mathrm{a}}$ & $77.92^{\mathrm{a}}$ & 1.02 \\
Ash & $61.20^{\mathrm{b}}$ & $63.27^{\mathrm{a}}$ & $63.59^{\mathrm{a}}$ & $63.62^{\mathrm{a}}$ & 2.39 \\
Haematological parameters & & & & & \\
Packed cell volume $(\%)$ & $31.0^{\mathrm{b}}$ & $33.0^{\mathrm{a}}$ & $33.0^{\mathrm{a}}$ & $32.0^{\mathrm{ab}}$ & 1.00 \\
& & & & & \\
Haemoglobin & $11.0^{\mathrm{ab}}$ & $12.7^{\mathrm{a}}$ & $10.3^{\mathrm{b}}$ & $11.2^{\mathrm{a}}$ & 2.40 \\
Blood urea (mg/dl) & 12.32 & 12.16 & 12.08 & 12.30 & 0.24 \\
Total protein (g/dl) & $9.04^{\mathrm{a}}$ & $8.50^{\mathrm{b}}$ & $8.40^{\mathrm{bc}}$ & $8.41^{\mathrm{bc}}$ & 0.64 \\
\hline SEM standard & & & & \\
\hline
\end{tabular}

SEM $=$ standard error of means

$\mathrm{a,b,c}$ means with the same superscripts on the same row are not significantly different $(\mathrm{p}>0.05)$

(A) 80VG:20\%CPL, (B) 70VG:30\%CPL, (C) 60VG:40CPL, (D) 50VG:50CPL,

different across the treatments, but were within the normal range (29.9 -33.6\%) reported for goats by Mitruka and Rawnsely (1977), which implies that the animals were not anaemic. The heamoglobin values obtained fell within normal values recorded for healthy goats (Benjamin, 1981 and Fajemisin et al., 2008) an indication that the silages seemed to be capable of supporting high oxygen capacity in the animals. The mean ranged value $(8.40-9.04 \mathrm{~g} / \mathrm{dl})$ for total protein obtained in this study was higher than the normal ranged values $(5.90-7.80 \mathrm{~g} / \mathrm{dl})$ reported by Mitruka and Rawnsely (1977). Total protein suggested good quality protein of the test diets, the higher the value of the total protein, the better the quality of the test feed stuff (Eggum, 1980). The values obtained for total protein in this experiment were higher than the range (6.12-7.20) reported by Fasae et al. (2012) for goats fed various cassava residues and grass mixtures. Values obtained for serum urea-nitrogen $(12.08-12.32 \mathrm{mg} / \mathrm{dl})$ were within the normal range, but above the range (2.91-3.82) reported by (5.56 and $4.24 \mathrm{~mm} / \mathrm{l}$ ) reported by Moloney et al. (1994) when grass silage supplemented with barley was fed, increase in blood urea value is an indication of poor protein quality. Urea values obtained in this study were within the normal range suggesting better urea nitrogen utilization. Woodman and Evan (1974) stated that a high value of urea-N indicates an inability of the animal to utilize nitrogen made available by digestion. Urea nitrogen accurately reflects the intake of effective rumen degradable protein.

\section{Conclusion}

The present study showed that ensiling vetiver grass with cassava peels improved the silage quality, enhanced intake and 
digestibility of vetiver grass. It did not have detrimental effects on the physiological status of the animals as reflected in the blood parameters measured. However vetiver silage without cassava peel exhibited poor silage characteristics and was rejected by the animals

\section{Acknowledgement}

The authors wished to acknowledge the contributions and support of the management and members of staff of National Center for Genetic Research and Biotechnology (NAGRAB), Moor Plantation, Ibadan, Oyo state, Nigeria.

\section{References}

Aderinola, O. A., Akinlade, J. A., Rafiu, T. A. and Fajinmi, T. 2008. Feed intake, digestibility and nitrogen balance of west African dwarf sheep and goat fed Vetiveria nigritana grass. Proceedings of $33^{\text {rd }}$ Annual Conference of Nigerian Society for Animal Production Olabisi Onabanjo University, Ayetoro. Pp 579-582.

Agricultural Research Council 1984. The nutrient Requirements of Ruminant Livestock, Supplement No 2 Commonwealth Agricultural Bureau, Slough, U.K.

Agricultural Research Council 1985. The nutrient requirements of farm animals. No, 2 Ruminants: Tech. Rev. and Sumannes.ARC, London

A.O.A.C. 1990. Official methods of analysis of the Association of Official A n a 1 y t i c a 1 c h e m is t s, $15^{\text {th }}$ edn. Washington, D.C. 1, 69-90.

Babayemi, O.J. 2009. Silage quality, dry matter intake and digestibility by African dwarf Sheepof Guinea grass (Panicum maximumcv ntchisi) harvested at 4 and 12 week regrowths.
African journal of biotechnology vol. 8(16): 3988-3989.

Babayemi, O.J. and Igbekoyi, J.A. 2008. Competition for resources in a changing world. New drive for rural development. Conference of the International Research on Food Security. Natural Resource Management and Rural Development, Tropentag, $7^{\text {th }}-9^{\text {th }}$ October 2008.

Benjamin, M.M. 1981. Outline of veterinary clinical pathology $\left(3^{\text {rd }}\right.$ Edition). The Iowa State University Press, Ames, Iowa, U.S.A.pp 5-162.

Coles, E. H 1986. Veterinary Clinica 1 Pathology $4^{\text {th }}$ Ed. W.B. Sanders Company. Philadephia, U.S.A.

Eggum, B.O. 1980. Blood urea measurement as a technique for assessing protein quality.British Journal of Nutrition. 4: 982-988.

Fajemisin, A.M., Fadiyimu, A.A. and Mokan, J.A. 2008. Performance and nitrogen retention in West African dwarf goats fed sun-dried Musa sapientum peels and Gliricidia sepium. Journal of Applied Tropical Agriculture. 15(special issue): 88 91.

Fasae, O.A., Idowu, O.M.O., Moronkola, A.I. and Ijaduola, O.A. 2012. Availability of cassava residues and by-products for goat production in cassava based farming system. Nigerian Journal of Animal Production 39(1): 161-168

Kung, I. and Shaver, R. 2002. Interpretation and use of silage fermentation analyses reports. Department of Animal and Food Science, University of Delaware, Newark, USA, DE 19717.

Lapar, M.L.A. and Ehui, S. 2003. Adoption of dual-purpose forages: some policy implications. 
Tropical Grassland 37:284-291.

Liu, J. X. and Cheng, Y. 2002.Issues of utilization and protection of formative vetiver grass pratacultural science 19 . 7; 13-16.

Mannetje .L 1999. Introduction to conference on silage making in the tropics in Mannetje (Ed.).Silage making in the tropics with particular emphasis on smallholders. FAO.Plant Production and Protection.Paper 161.

McDonald, P., Edward, R.A, and Greenhalgh, J.F.D. 1995. Animal nutrition, $5^{\text {th }}$ edition, Longman Scientific and Technical, England.

Meneses M.D, Megias J, Madrid A, Martinez-Teruel F, Hemandez J, Oliva, $\mathbf{J} 2007$. Evaluation of the phyto sanitary, fermentative and nutritive characteristics of silage made from crude artichoke (cynarascolymus L) by -product feeding for ruminant. Small Ruminant Research. 70:292296.

Mitruka, B.M. and Rawnsley, M. 1977. Clinical Biochemical and Haematological reference values in normal experimental animals. Masson publishing New York

Moloney, A.P., Almiladi, A.A., Drennan, M.J., Galfrey, P.J. 1994. Rumen and blood variables in steers fed grass silage and rolled barley or sugar cane $\mathrm{m} \quad \mathrm{o} \quad 1$ a $\mathrm{s}$ s e $\mathrm{s}-\mathrm{b}$ a $\mathrm{s}$ e $\mathrm{d}$ supplementation. Animal Feed Science and Technology. 50:37-54.

National Research Council (1981). Nutrient requirement of goats. Angora, Dairy and meat goats in temperate and tropical countries.National Academy of Sciences Washington, D.C.
Nguyen, V.H., Nguyen,T.H.N., Vo, A.Q. and Pham.V.N. 2004. Digestibility of Nutrient Content of Vetiver grass by Goats Raised in the Mekong Delta, $\mathrm{V} i \mathrm{e} \quad \mathrm{t}$ a $m$. www.vetiver.org/proceeding/nhanpdf

NRC, (1993). National Research Council Vetiver Grass; a Thin Green Line against Erosion. National Academy Press, Washington D.C

Oduguwa, B.O., Jolaoso, A.O. and Ayankoso, M.T. 2007. Effect of ensiling on the physical properties, chemical composition and mineral contents of Guinea grass top silage.Nigerian Journal of Animal Production. 34:100-106

SAS 2002. Statistical Analysis Systems, User'Guide,Version 8 ed., SAS Institute Inc.SAS Campus Drive Cary, North Carolina, USA.

Toro, G and Ackermann, P. G 1975. Practical Clinical Chemisty $1^{\text {st }}$ Ed. Little Brown and Company, Tropical Grassland 37:284-291.

Truong, P.N.V.and Baker, D. 1998. Vetiver grass system for environmental protection. Tech. Bull. No.1998/1,PRVN/ORDPB, Bangkok, Thailand.

Van Soest, P.J., Robertson, J.B. and Lewis, B.A. 1991. Methods for dietary fibre, neutral detergent fibre, and non-starch polysaccharides in relation to animal nutrition. Journal of Dairy Science 74:3583-3597

Woodman, H.E. Evans, R.E. 1974. The nutritive value of fodder cellulose when fed to ruminants and pigs. Agricultural science xxxvii 202-223.

Received: 10th January, 2014 Accepted: $22^{\text {nd }}$ February, 2015 